\author{
SANATIN VE SANAT EĞİTIMININ DEĞER OLUŞTURMADA \\ YERİ VE ÖNEMI' ${ }^{1}$
}

\title{
THE SIGNIFICANCE OF ART AND ART EDUCATION IN THE PROCESS OF VALUE FORMATION
}

\section{Erdem $\ddot{U} N V E R$}

\author{
Atılım Üniversitesi, Güzel Sanatlar, Tasarım ve Mimarlık Fakültesi Ankara / Türkiye
}

Öz: Geçmişten bugüne tüm kültür dönemleri ve toplumsal yapılar zamana uygun ortak amaçlar oluşturdular. Duygu, düşünce ve davranıș boyutuyla bir bütünü ifade eden insan iyi, doğru, güzel kavramlarında pragmatik boyutu ön plana çıkan normlarla birliğe, beraberliğe, güçlü olmaya ve mutluluğa yöneldi. Dine, ahlaka, sanata ve genelde bilgiye dönük bu kavramlar, değerler kategorisinde hep yukarılarda tutuldu ve önemsendi. Illkel eğitim öğretileri dâhil farklı düzeylerdeki eğitim sistemleri davranış oluşturmada sözü edilen alanları temel sorun olarak gördü. Aslında toplumların kişiliklerini belirleyen, onlara anlam veren kültür dokuları, bu değerlerden başka bir şey değildir. Birlik duygusu, hoşgörü, sevgi- saygı, estetik, kültürel miraslara karșı duyarlık ve benzeri değerler kültürel alanın elemanlarıdır. Değerler nasıl insana özgü ise, sanat ve eğitimi de insana özgüdür. $\mathrm{Bu}$ nedenle sanat eğitimi insanlığın eğitimidir. Tarihsel süreçte toplumsal ihtiyaçlara bağlı olarak amaç, teknik ve yöntemlerle dönemin mizacına uygun biçimlenen sanat ve sanat eğitimi, değerler sistemi icinde en az bilim ve teknoloji kadar önem kazandı. Çünkü bilim, teknoloji, külttür ve sanat birbirini tamamlamanın ötesinde, birbirini güdüleyerek gelişmenin temel dinamiği oldular. Geçmişte usta-çırak ilişkisi ile öğretilen ve üretilen, zaman içinde eğitim programlarına kendi ilke ve amaçları ile giren sanat eğitimi; bireylerin ulusal ve evrensel değerleri tanımalarını, benimsemelerini, geliştirmelerini ve bu değerlere saygı duymalarını sağlar. Ayrıca, liderlik, yaratıcı ve üretici düşünce yeteneklerinin ulusal ve toplumsal bir anlayışla ülke kalkınmasına katkıda bulunacak sekilde geliștirmelerini, bilimsel düşünce ve davranışlarla estetik değerleri birleştiren, üretken, sorun çözen kendini gerçekleştirmiş bireyler olarak yetişmelerine olanak veren süreçleri kapsar.

Anahtar Kelimeler: Sanat, Sanat Eğitimi, Değerler
Abstract: Each period of culture and social structures have created common objectives appropriate for the epoch from the past to the present. Embodying the dimensions of thought and behaviour, man has tended towards unity, cooperation, strength and happiness with the norms in which the pragmatic dimension comes to the fore within the concepts of good, right and beautiful. The notions that are based on religion, art and knowledge, in general, have been considered important in values category. Varied level of education systems including even the primitive education teachings have regarded the above mentioned disciplines as basic problems. Actually, cultural textures, which determine the characteristics of societies, are basically these values. Sense of unity, tolerance, love-respect, aesthetic, and sensitivity to cultural heritage and similar values are the elements in a cultural realm. Values are peculiar to human beings. Similarly art and art education are also peculiar to human beings. Consequently, art education refers to the education of humanity. In the historical process, art and art education, which have been shaped with objectives, methods and techniques, based on the social needs, in accordance with the characteristics of the era, have become crucial as much as science and technology in the value system. Thus science, technology, culture and art have become the fundamental dynamics for the development by not merely complementing but by stimulating each other as well. Art education, based on teaching master-apprentice relationships in the past, and included in education programmes with its own principles and objectives in the course of time, enables individuals to be familiar with national and universal values, to adopt, to develop, and to respect these values. Further to this, art education comprises processes which help individuals to improve their leadership, creative and productive thinking skills to contribute to the development of their countries in national and social terms, to combine scientific thoughts and behaviours with aesthetic values, and to be productive, problem solving, and self-fulfilling individuals.

Key Words: Art, Art Education, Values

(1) Sorumlu Yazar: Erdem ÜNVER, Attlım Üniversitesi, Güzel Sanatlar, Tasarım ve Mimarlık Fakültesi Ankara / Türkiye erdemunver55@gmail.comGeliş Tarihi / Received: 15.12.2014 Kabul Tarihi/Accepted: 19.02.2015 Makalenin Türü: Typeofarticle (Derleme - Literatür / LiteratureCollection) Çıkar Çatışması / Conflict of Interest:Yok / None"Etik Kurul Raporu Yok - NoneofEthicsCommittee" 


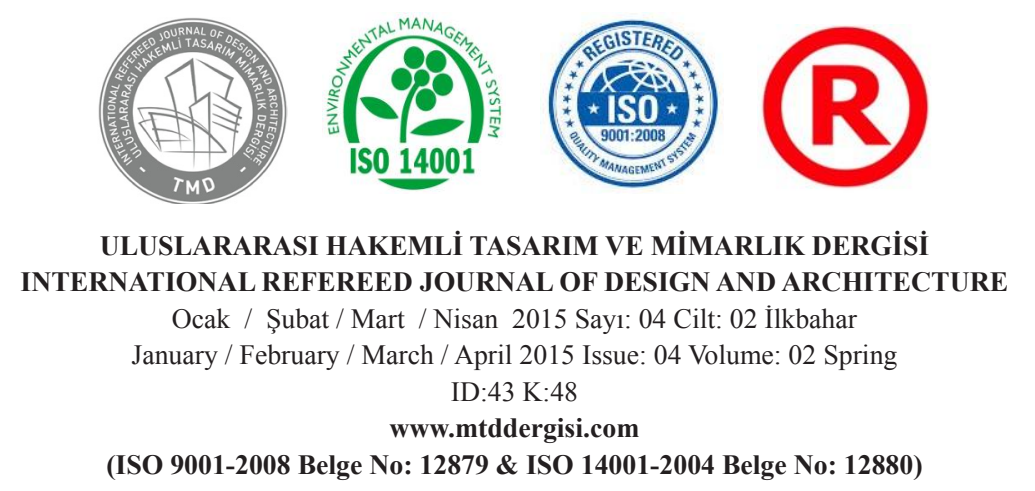

\section{GíRIŞ}

Gezegenimizde nitelik ve niceliksel gelişme gösteren tek varlık insandır. Düşünme, sorgulama, eylem becerileriyle ilkel yaşantı düzeyinden bilim çağına ulaşmıştır. Bilgi, duygu ve davranış özelliğinin anlamlı birlikteliği varlığa bilim, teknoloji, kültür ve sanatla yeni anlamlar yüklemiştir. Aslında bunların hepsi insanın varlığa eklediği değerlerden başka şeyler değildir.

Değerler konusu geçmişten bugüne felsefi ve sosyolojik bağlamda farklı tanımlamalara açık oldu ve felsefi boyutta öznel ve nesnel açılardan değerlendirildi. Hazcı değerler; haz ve acı, bilişsel değerler; doğru ve yanlış, ahlaki değerler; iyi ve kötü, estetik değerler; güzel ve çirkin, dinsel değerler; sevap ve günah şeklinde ifade edildi (Özlem, 2002: 285).

Felsefeden ayrılarak ayrı bir bilim dalı olan sosyoloji de toplumun sosyal ve kültürel öğeleri olan değerler konusunu yeterince tartışmaya açtı. Değerler bireylere, gruplara, hedeflere, sosyal ve kültürel yapılara verilen önem üzerindeki değerlendirmelere dayanan ölçütlere göre tanımlandı. Theodorsonlar değerleri ' Özel eylemleri ve amaçları yargılamada temel bir standart sağlayan ve grup üyelerinin güçlü duygusal bağl1lıkları olan soyut ve genelleşmiş prensipler" olarak tanımladılar (1979: 455). Tanım ne olursa olsun değerler, sosyal normlar içinde somut davranışların genelleşmiş standartlarını sağlamaktadır. Eylemleri belirleyen birçok değer standardının olduğu ve birey boyutunda bakıldığında, sosyal yaşantıda herhangi bir eylem standardına göre şekillenmediği görülür. Ancak genel anlamda değerler arasında bir uzlaşma olduğu söylenebilir. Sosyal değerler davranışlara yön veren, maddi ve manevi niteliklere sahip ortak kabul gören ölçütlerdir. Toplumların ulaşacağı ya da ulaşmak istediği yeri belirlerler.

Ekonomi, siyaset, aile, eğitim, din, hukuk gibi kurumlar kendilerine özel değerler oluşturur ve barındırır. Ancak bu kurumlar nasıl toplumsal yapının tamamlayıcıları ise, değerleri de birbirinden bağımsız değildir. Bireyin bu değerleri benimsemesi çevresine, topluma uyumunun bir gereğidir. Toplumsal roller de kişinin değer algısı ve davranış biçimlerini etkiler. Bir hukuk insanı ile bir sanatçının, bir din adamının ya da bir tüccarın değer dereceleri birbirinin aynısı değildir. Çünkü durduğu yer farklı algı ve yargılamalara neden olabilir. Başka bir deyişle toplumsal kurumların tümü kendilerine ait değerler içerir (Özensel, 2003: 236).

Değerler toplum yaşamı içinde adetlerin, geleneklerin, inanç sistemlerinin yaşatılmasıyla sürdürülürken, hızla değişen dünyada, asıl belirleyicinin eğitim olgusu olduğu bilinmelidir. Adler ' 'Eğitimler hala insan ruhuna ilişkin geçerli bilgiler vermekten uzak, özgürlük devleri yaratır, baskı öldürür" derken bir bakıma sanat ve sanat eğitiminin önemini vurguluyor ve fiziksel bozukluklar, aile huzursuzluğu, ekonomik yetersizliklerin toplumun duygusal gelişimini olumsuz yönde 


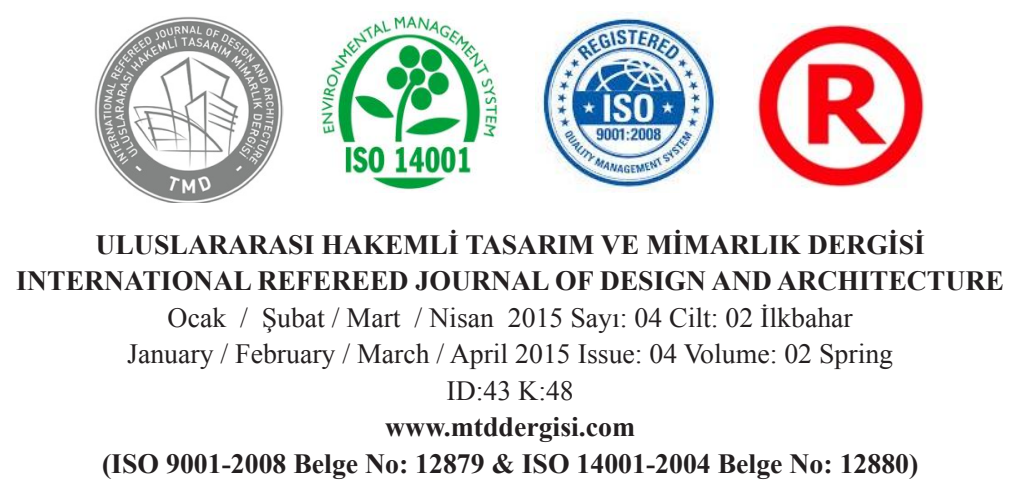

etkilediğini, genelde bireyi değiştirme sürecinin

4- Nitelikle sanata önem veren yaklaşım.

basit olmadığını ifade ediyor (2013: 18-24).

Tüm toplumsal sorunların çözümü için gerekli

olan eğitim insanı nefis, akıl ve sezgi yönünden bütünleştirmeyi amaçlamaktadır. Bu durum ruh ve bedenin, canlılık ve rasyonelliğin, bilinç ve bilinçaltının, duygusallık ve entelektüelliğin dinamik birlikteliğidir (Çınar, 2006: 66).

Sanat ilk insandan bu yana yaradılıştan gelen düşünceye ve istendik davranışa bağlı, üretme ve estetik yeteneğinin sonucudur. Zamana bağlı amaç, anlam ve ifade farklılıklarıyla devam etmektedir. İnsana özgü bir faaliyettir, insanın olduğu her yerde vardır. İlkel dönemlerde insanüstü güçlere sahip kişilerin uğraş alanı olan sanat, zamanla usta-çırak ilişkileriyle, daha sonra kurgulanmış eğitim sistemi içinde insanın ve insanlığın gelişmesinde etkin rol oynadi.

Sanat ve insanın içiçeliği sanata ve sanat eğitimine tarihsel süreçte zamana bağlı olarak farklı amaçların yüklenmesine neden oldu. Örnek teşkil etmesi ve etki alan genişliğini göstermesi nedeniyle Almanya' da sürece dayalı olarak şöyle bir amaç sıralaması yapmak olasıdır:

1- Nitelikli ve estetik ürünler sunmayı amaçlayan ekonomik yaklaşım.

2- Endüstri üretiminin zevksizliğini gidererek mutlu bir yaşama ulaşabilme.

3- Teknolojinin getirdiği olumsuzlukları gidermeye yönelik romantik anlayış.

5- Halk sanatını sanat eğitimiyle birleştirmeyi amaçlayan Bauhaus ekolü.

6- Kent yaşamından uzaklaşarak doğaya dönüşü özendiren psikolojik boyutu olan yaklaşım.

7- Savaş zamanında ülke savunmasına katkı veren yaklaşım.

8- Sanatı halkın anlayabileceği dilde anlatmayı amaçlayan yaklaşım.

9- Yaşamı düzenleme kaygıları taşıyan dinsel, ahlaksal, tinsel boyutlu yaklaşım.

10- Evrensel ölçülerde çocuğu önemseyen yaklaşım.

11- İçerikten fazla biçime önem veren yaklaşım.

12- İdeolojiye hizmet eden yaklaşım.

13- Yaratıcılık ve terapiye önem veren yaklaşım.

14- Kitle eğitim araçlarına yönelik kaygıları içeren eleştirel eğitim yaklaşımı (San, 1983: 196).

Yukarıda ifade edilen yaklaşımlar ya da benzerleri sanayileşme sürecini yaşayan farklı bölgelerdeki toplumlar için de geçerlidir. Bu amaçların birkaç tanesi aynı anda amaç haline getirilmiş olabilir. Ancak günümüzde bilim ve teknolojinin gelişimi, yaşamın tüm alanlarında olduğu kadar kültür üretiminde, sanat ve sanat eğitiminin değişiminde de belirleyici rol oynadı. Sanat eğitimini kendi amaçları dışında araç haline getiren sözü edilen 


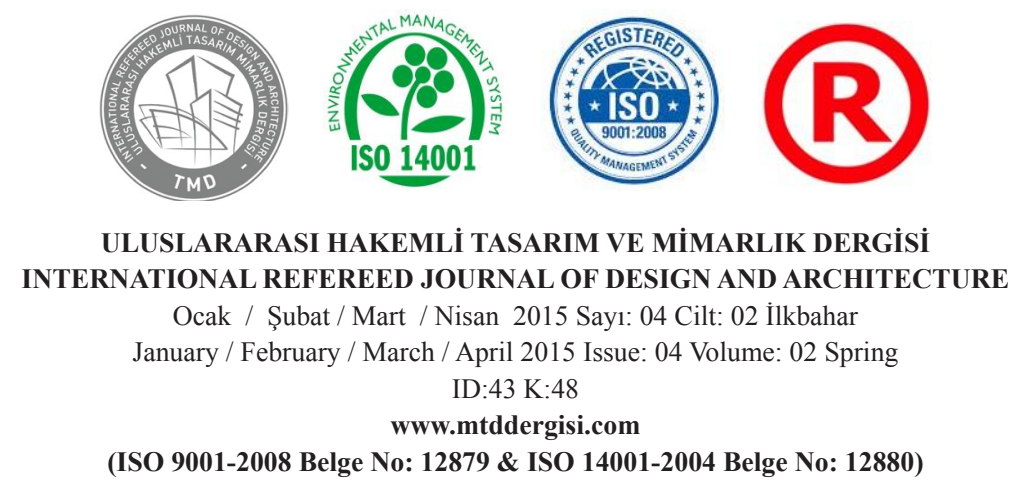

yaklaşımların, alan amaçlarının gerçekleşmesine zarar vermekle birlikte bireyin toplumuna faydalı olması yönünde katkı sağladığı söylenebilir.

Bilimsel çalışmalar, insan beyninin sağ yarım küresinin görsel, artistik alan bilgi ve becerilerine, sol yarım kürenin bilimsel alan bilgilerine dönük işlevleri yerine getirdiğini saptamıştır. Bilimin, insanın bilgisel deneyimlerini, sanatın duyumsal deneyimlerini örgütlediğini söyleyen Thomson, bilim ve sanatın dünyayı değiştirmeye çalıştığını, bilim insanının doğayla nesnel ilişkiler, sanat insanının öznel ilişkiler kurduğunu söylemektedir. Ancak her ikisinin de bilgimizi zenginleştirdiğini, doğaya üstün gelmenin yöntemleri olduğunu, bilim ve sanatın birbirinden ayrı düşünülemeyeceğini ifade etmektedir (1979: 30). Sanat eğitiminin insanın bilgi, duygu ve davranış alanlarını bir bütün olarak eğittiği gerçeğinden hareketle, sanat eğitimi verilmeden tam bir eğitim verilmiş sayılmaz demek mümkündür. Benzer bir ifadeyle sanat ve eğitimi bilgi ve bilinç veren, yücelten, arındıran geniş kapsamlı bir alana sahiptir. Deneyim, araştırma, derin düşünme ve eylem bireyi çok yönlü geliştirir. Sanatsal değerler yanında toplumsal, tarihsel değerlerin öğretilmesinde de etkin eğitim ve öğretim alanıdır. Araştırma, düşünme, eylem, eleştiri ve ürün süreci eleştirel bakmayı, yanlış olanı düzeltmeyi, yeniden düzenlemeyi kazandırır (Kırışoğlu, 2014: 9).

Günümüzde görsel medya ve bilişim sistemlerindeki hızlı gelişmenin beraberinde getirdiği imge yoğunluğu, görsel sanatların önemini daha da ön plana çıkartmıştır. Popüler kültür ve tüketime yönlendirme karşısında iyi, kötü, güzel, çirkin ve değerli adına farkındalığın geliştirilmesi gereklidir. $\mathrm{Bu}$ nedenle güncel kültürü yaşamakla birlikte, gelenekseli bilmek, çağdaş, tarihsel, toplumsal olanı eleştirel bir yaklaşımla öznel ve özgün bir şekilde anlatma önemli bir gereklilik olmaktadır.

\section{KÜLTÜREL VE SANATSAL DÖNEM- LERDE SANATIN TOPLUMSAL ANLAMI}

İnsanlık tarihi sanat tarihi verileriyle anlamını buldu. Sanat her dönemde toplumların kültür kodları, somut kültür değerlerine dönüştürüldü. Bir anlamda primitif dönemden bugüne insanlığın ürettiği değerlerin görsel formları oldular.

Primitif dönemde sanat yaşamla eş tutulmaktadır. Doğada var olabilmenin, hayatı yaşanır kılmanın bir aracıdır sanat. Büyüsel gücü yanında günlük yaşamın diğer ihtiyaçlarını gidererek toplumun temel değer sistemlerini belirleyen anlam taşıdı. İnsanların temel ihtiyaçlar kategorisinde bulunması binlerce y1l sanatın belirleyici bir rol oynamasına neden oldu.

Arkaik dönemde güneşli ve sulu alanlara yerleşerek toprak kültürü düzeyine ulaşan toplumlar ilk Monarşik yönetim biçimlerini oluşturdular. Güçlü yönetici gücünün sanatın görsel formlarında somutlaşmasını sağladı. Bu formlar yönetim erkinin, tanrısal özelliklerin, onların yaşam biçimlerinin ifadeleri olmakla birlikte, toplumsal yaşantı ve değer ölçülerinin, başka bir deyişle kültürel dünyalarının somut verileri haline geldi. 


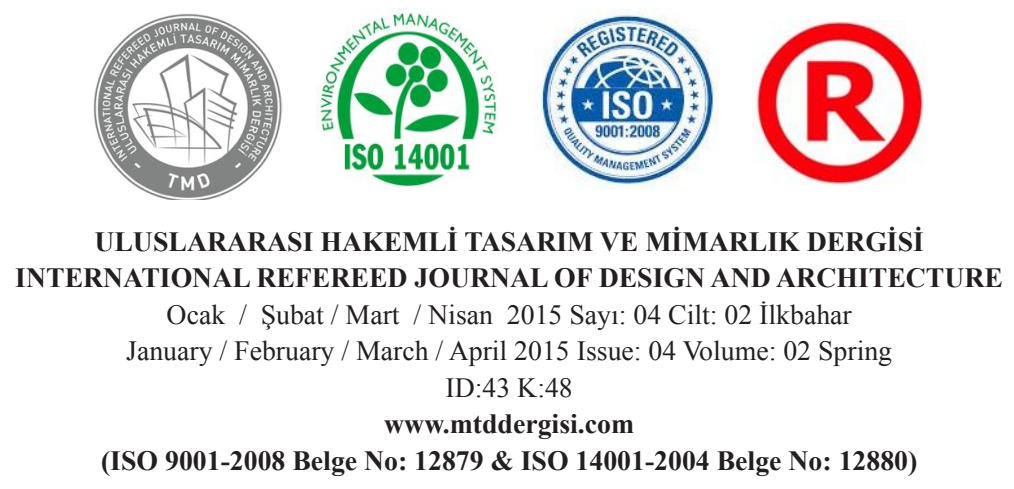

Klasik dönem insanın merkeze alındığı, dünyevi devlet anlayışının egemen olduğu, sanatın da insan merkezli olduğu dönemdir. İnsanı ve insana özgü ölçüleri benimseyen klasizm, modern dünyayı müjdelerken insani değerlerin önemsenmesi ve gelişmesine büyük katkılar sağladı.

Barok dönemde büyüyen krallıklar sahip olduğu asiller sınıfinın yanında burjuva sınıfinın oluşmasını sağladı. İmparatorluk gücü ve zenginliği kültürel ve sanatsal alanda gösteriş ve prestiji ön plana çıkarttı. Daha çok sanat eseri ve sanatçıya sahip olmak aslında sanatın korunmasını ve üretimin artmasını sağladı. Sanatsal üretim kültürel zenginleşmeye ve dönem değerlerinin somutlaşmasına katkida bulundu.

Sanayi döneminde insan gücü yerine makinenin geçmesi her şeyden önce üretimin, insan-doğa, insan-insan ilişkilerinin ve kentleşmenin hızla değişmesine neden oldu. Bu durum yeni bir yaşam ve değerler sistemlerinin oluşması anlamına geliyordu. Geleneksel sanatın da seri üretime geçmesi, estetik sorunlara neden oldu. Sermayenin egemenliğinin ve yeni kent yaşamının duygulara olumsuz yansimaları, bireysel ve toplumsal psikolojik sorunlara zemin hazırladı.

Yakın dönem pozitif bilimlerle varlığı algılama ve sorgulama yöntemlerini temelden değiştiren bilim çağını getirdi. Yeni dönem tüm yaşamı, düşünce sistemlerini, kültürü, sanatı ve üretim- tüketim ilişkilerini farklı boyutlara taşıdı. Bilim- teknoloji, kültür ve sanatın birlikteliği değişimin, dönüşü- mün ve gelişmenin temel belirleyicileri oldular. Ulusal ve evrensel değerlerin oluşmasında bilim kadar, teknoloji kadar, kültür ve sanatın da rolü kendini hissettirdi.

\section{MILLİ EĞİTIMIN VE SANAT EĞİTİ- MININ AMAÇLARI}

\subsection{Türk Milli Eğitiminin Genel Amaçları:}

Türk Milletinin bütün fertlerini,

1- Atatürk İnk1lâp ve İlkelerine ve Anayasada ifadesini bulan Atatürk Milliyetçiliğine bağl1; Türk Milletinin milli, ahlaki, insani, manevi ve kültürel değerlerini benimseyen, koruyan ve geliştiren; ailesini, vatanını, milletini seven ve daima yüceltmeye çalışan; insan haklarına ve Anayasanın başlangıcındaki temel ilkelere dayanan demokratik, laik ve sosyal bir hukuk devleti olan Türkiye Cumhuriyetine karşı görev ve sorumluluklarını bilen ve bunları davranış haline getirmiş yurttaşlar olarak yetiştirmek;

2- Beden, zihin, ahlak, ruh ve duygu bakımından dengeli ve sağlıklı şekilde gelişmiş bir kişiliğe ve karaktere, hür ve bilimsel düşünme gücüne, geniş bir dünya görüşüne sahip, insan haklarına saygıll, kişilik ve teşebbüse değer veren, topluma karşı sorumluluk duyan; yapıcı yaratıcı ve verimli kişiler olarak yetiştirmek;

3- İlgi, istidat ve kabiliyetlerini geliştirerek gerekli bilgi, beceri, davranışlar ve birlikte iş görme alışkanlığı kazandırmak suretiyle hayata hazırlamak ve onların, kendilerini mutlu kılacak 


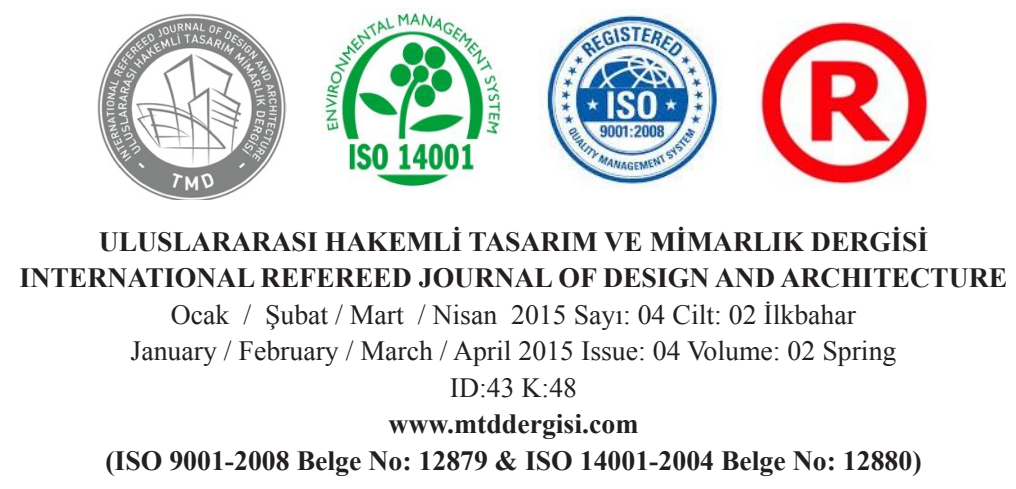

ve toplumun mutluluğuna katkıda bulunacak bir meslek sahibi olmalarını sağlamak;

Böylece, bir yandan Türk vatandaşlarının ve Türk toplumunun refah ve mutluluğunu arttırmak, öte yandan milli birlik ve bütünlük içinde iktisadi, sosyal ve kültürel kalkınmayı desteklemek ve hazırlamak ve nihayet Türk Milletini çağdaş uygarlığın yapıcı, yaratıcı seçkin bir ortağı yapmaktır.

Özel amaçlar başlığı altında da ' Türk Eğitim ve öğretim sistemi, bu genel amaçlarla gerçekleştirilecek şekilde düzenlenir ve çeşitli derece ve türdeki eğitim kurumlarının özel amaçları, genel amaçlara ve aşağıda sıralanan temel ilkelere uygun şekildetespit edilir"'denmektedir(http:// ahsar.blogcu.com/).

Bu ilkeler:

1. Genellik ve Eşitlik

2. Toplumun Gereksinimleri ve Bireyin Yetenekleri

3. Yöneltme, Yetiştirme ve Başarı

4. Zorunlu Eğitim ve Öğretim Hakkı

5. Fırsat ve Olanak Eşitliği

6. Her Yerde Eğitim

7. Karma Eğitim

8. Bilimsellik ve Çevresellik

9. Planlilik
10. Atatürk İlke ve Devrimleri ile Atatürk Milliyetçiliği

11. Ulusal Ahlak ve Kültürün geliştirilmesi

12. Türk Dili ve Yabancı Dil Öğretimi

13. Laiklik ve Din Kültürü Eğitimi

14. Demokrasi Bilincinin Geliştirilmesi

15. Okul ile Ailenin İşbirliği

16. Uyumluluk

17. Eğitim Etkinliklerinin Yürütülmesi(http:// ahsar.blogcu.com/).

Nasıl eğitim bir süreçse, sanat eğitimi de okul öncesi dönemden başlayarak yaşam boyu devam eden bir süreçtir. Başta ailelerin bilinçlendirilmesi olmak üzere kreşler, anaokulları, ilköğretim, ortaöğretim ve üniversiteler yukarıda sözü edilen amaç ve ilkeler doğrultusunda programlarını tespit etmek, bilişsel, duyuşsal ve psikomotor davranışları geliştirmek zorundadırlar.

\subsection{Sanat Eğitiminin Amaçları}

Okul öncesinde el becerileri kazandırmaya dönük basit çalışmalarla fark edebilme, muhakeme yeteneği ve karşılaştırma yapabilme amaçlanmaktadır. İlköğretim ve ortaöğretim kurumlarında tasarım elemanları ve kullanımı, görsel ilişkiler, doğa bilinci, duygu ve düşüncelerin anlatımı, müze, sanat tarihi ve tarih bilinci, iki ve üç boyut bilinci, somut ve soyut kavramlar bilinci, sanat dönemleri, farklı tekniklerde çizgi, renk ve üç boyutlu anlatımlar 


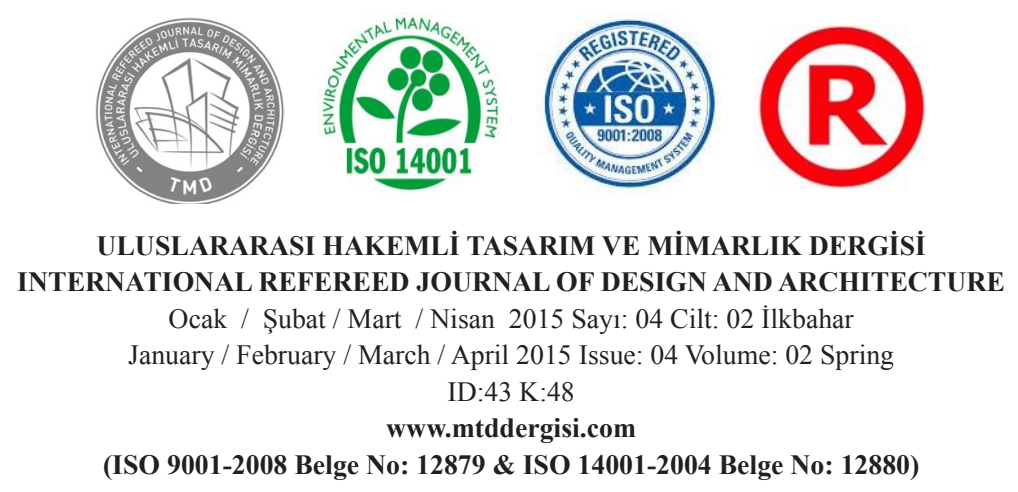

ve benzeri bilgi ve çalışmalarla varlık hakkında bilgilenme ve istendik davranışlanı sergileyebilme amaçlanmaktadır.

Güzel Sanatlar Liseleri öğrencilerin; İlgi, istek ve yetenekleri doğrultusunda güzel sanatlar eğitimi ile ilgili temel bilgi ve beceriler kazanmalarına yönelik eğitim- öğretim görmelerini ve alanlarında başarılı bireyler olarak yetişmelerini, güzel sanatlarla ilgili yükseköğretim programlarına hazırlanmalarını, Türk sanat, kültürüne katkıda bulunan ve başarıyla temsil eden bireyler olarak yetişmelerini, iş birliği içinde çalışma ve dayanışma alışkanlığı kazanarak takım ruhu ile hareket etmelerini, alanları ile ilgili araştırma yaparak yorum ve uygulama yetkinliğine ulaşabilmelerini, milli ve milletlerarası sanatsal faaliyetleri takip ederek bilgi ve kültürlerini geliştirmelerini, sanatçı duyarlığını benimseyen bireyler olarak yetişmelerini amaçlamaktadır(http://mebk12. meb.gov.tr/).

İlk ve ortaöğretimin özetle sözü edilen bu amaçlarından hareketle Türkiye Yükseköğretim Ulusal Yeterlilikler Çerçevesi lisans eğitiminin çıktılarını şu şekilde belirlemektedir:

Bilgi (kuramsal, uygulamalı) boyutunda; Ortaöğretimde kazanılan yeterliliklere dayalı olarak alanındaki güncel bilgileri içeren ders kitapları, uygulama araç-gereçleri ve diğer bilimsel kaynaklarla desteklenen ileri düzeydeki kuramsal ve uygulamalı bilgilere sahip olmak.
Beceriler (Kavramsal/ Bilişsel, Uygulamal1) boyutunda; Alanında edindiği ileri düzeydeki kuramsal ve uygulamalı bilgileri kullanabilmek, alanındaki kavram ve düşünceleri bilimsel yöntemlerle inceleyebilmek, verileri yorumlayabilmek ve değerlendirebilmek, sorunları tanımlayabilmek, analiz edebilmek, kanıtlara ve araştırmalara dayalı çözüm önerileri geliştirebilmek.

Kişisel ve mesleki yetkinlikler bölümünde;

Bağımsız çalışabilme ve sorumluluk alabilme yetkinliği; Uygulamada karşılaşılan ve öngörülemeyen karmaşık sorunları çözmek için bireysel ve ekip üyesi olarak sorumluluk alabilmek, sorumluluğu altında çalışanların mesleki gelişimine yönelik etkinlikleri planlayabilmek ve yönetebilme.

Öğrenme yetkinliği boyutunda; Edindiği bilgi ve becerileri eleştirel yaklaşımla değerlendirebilmek, öğrenme gereksinimlerini belirleyebilmek ve öğrenmesini yönlendirebilmek.

İletişim ve sosyal yetkinlik alanı; Alanıyla ilgili konularda ilgili kişi ve kurumları bilgilendirebilmek; düşüncelerini ve sorunlara ilişkin çözüm önerilerini yazılı ve sözlü olarak aktarabilmek, düşüncelerini ve sorunlara ilişkin çözüm önerilerini nicel ve nitel verilerle destekleyerek uzman olan ve olmayan kişilerle paylaşabilmek, bir yabancı dili kullanarak alanındaki bilgileri izleyebilmek ve meslektaşlanı ile iletişim kurabilmek, alanının gerektirdiği düzeyde bilgisayar ve yazılımı ile birlikte bilişim ve iletişim teknolojilerini kullanabilmek. 


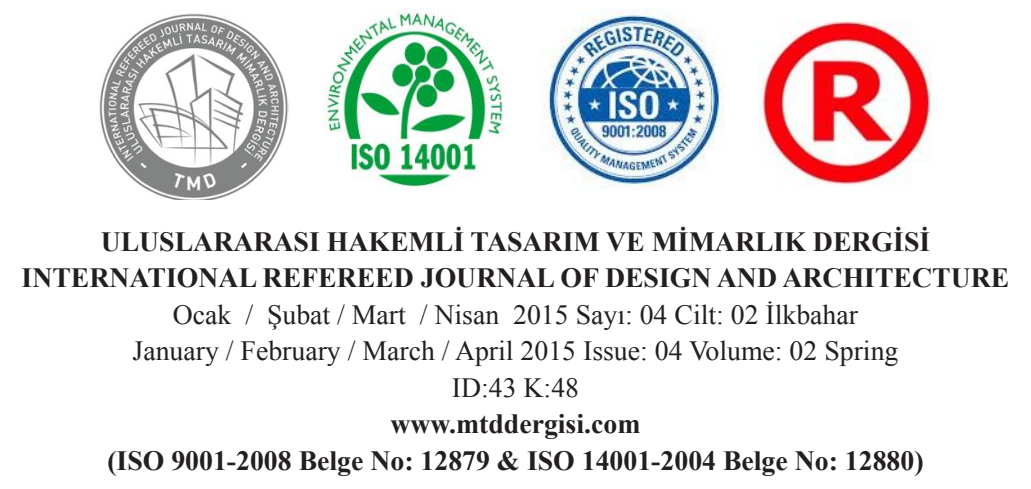

Alana özgü ve mesleki yetkinlik alanında; Alanı ile ilgili verilerin toplanması, yorumlanmass, duyurulması ve uygulanması aşamalarında toplumsal, bilimsel ve etik değerlere sahip olmak, sosyal hakların evrenselliğine değer veren, sosyal adalet bilincini kazanmış, kalite yönetimi ve süreçleri ile çevre koruma ve iş güvenliği konularında yeterli bilince sahip olmak şeklinde tespit edilmiştir (http://tyyc.yok.gov.tr/).

\section{4- DEĞERLENDİRME}

Gelişmiş ülkelerin baskın kültürel değerleri görsel imgelerle yoğun biçimde diğer toplumları etkilemektedir. Kültürel kimliğe zarar veren bu etkilerden kurtulabilmenin ve milli bir kimlik oluşturabilmenin en önemli yolu, sanat eğitimi kapsamında verilebilecek görsel kültür eğitimidir. Görsel kültür eğitiminin kapsamı, içeriği ve öğretim amaçlarıyla farklılık göstermekle birlikte; eleştirel bir kimlik kazandıracak uygulamalara yer vererek edilgen bir birey yerine etkin ve katılımcı bir birey olmayı sağlar. Dünyanın küçüldügüü üretim ve tüketim ağlarının uluslararası boyuta geldiği günümüzde üretim nedeninin, anlamının, üretenin niyetinin bilinmesi, estetik yönü ile birlikte ekonomik, siyasi, sağlık ve diğer yönlerinin irdelenerek duyarlı davranılması gerekir (Kırışoğlu, 2009: 46). Günün şartları ile belirlenen eğitim anlayışı, kültürlerin etkileşimi, etkileşimde ortak insani değerlerin dışındaki emperyalist nedenlere duyarsız kalmamalıdır. Tek başına ekonomik yayılma kültürel kimliğe tehdit olabilecek güçtedir.
Sanatın evrensel bir dil olması, teknik ve estetik ortaklığı gündeme getirebilir. Eser oluşturma, eleştirel düşünme, toplumsal ve kültürel ilişkiler kurulması eğitim süreçlerinde değerlendirilebilmelidir. Böyle bir yaklaşımla kurgulanan görsel kültür eğitimi nesnelere bağlamsal yaklaşmayı gerektirirken; toplumsal, kültürel, politik, ekonomik ve tarihsel konulara yönelim disiplinlerarası bir boyutu zorunlu görür.

Sanatın evrenselliği yanında, estetik değerlerin üretildikleri ortam ve anlamlarla bütünleştiği unutulmamalıdır. Etkileşimin doğallığı kadar yöreselden, ulusal ve evrensele giden çizgide devamlılık sağlamak ve toplumsal değerleri diğer ülkelere taşıyabilmek de önemsenmelidir (Kırışoğlu, 2009: 51).

Sanatın ve eğitiminin estetik, eleştiri, sanat tarihi ve uygulama alanlarıyla kültür oluşturucu gücü, görsel kültür eğitiminin disiplinlerarası yaklaşımı, toplumsal değer yargılarının oluşumunun belirleyicileridir. Kirschenbaum, değer gerçekleştirme yaklaşımında bireyin kendi duygu, inanç ve önceliklerinin farkına varması, onurlu, eleştirel ve yaratıcı düşünmesi, iletişim ve sosyal becerilerinin geliştirilmesi önemsenmelidir derken; sanat ve sanat eğitiminin önemine gönderme yapmaktadır (1995: 40). Karakter eğitimi yaklaşımında; kendine, çevresine saygıll, sorumlu, dürüst, güvenilir, şefkatli, yardımsever, azimli, disiplinli, sadık, cesur, iş ahlakına sahip bireyleri tanımlayan Lickona aslında genel anlamda 


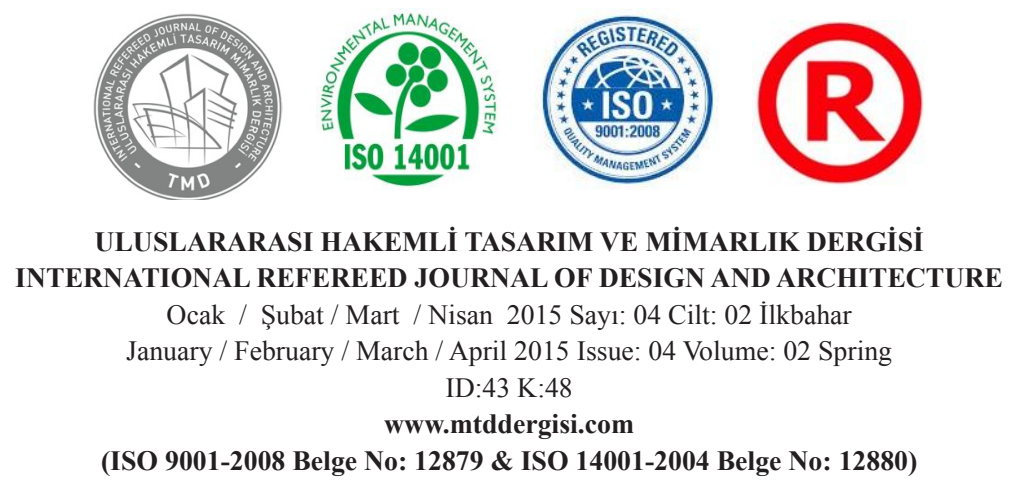

eğitime, özelde sanat eğitimine işaret etmektedir (1992: 35).

Tarihi verilerin büyük bölümü ve sanat tarihi verileri bize ulaşan sanat eserlerinde ortaya çıtıt. İnsanlığa ve uygarlığa büyük katkılarda bulunan bu ürünler yükssek düzeyde duygu ve düşünce ürünleridir. Onlar toplumların yaşam ve yaratma düzeylerini yansitırlar. Bu nedenle sanat tarihi bir anlamda insanlığın tarihidir.

\section{5- SONUÇ}

Sanat dışavurum olanağıyla ruh sağlı̆̆ına, kişinin kendisini kanıtlamasına katkıda bulunmaktadır. Her alanda kullanılabilecek yaratıcılığı, estetik yönü, yarg1 gücünü ve çok yönlü gelişmeyi sağlamaktadır. Özgür anlatım olanağı birey olabilme sürecini hızlandırır. Sanat araç olsa da, amaç olsa da ontolojik yapısı toplumsal etkisini açığa çıkartır. Bu nedenle sanat ve eğitiminin kişiye kazandıracağı değerleri hiçbir ders sağlayamamaktadır. Bireysel, toplumsal ve evrensel ilişki kurmanın en etkin yoludur. Soyut düşünme ve görsel okur- yazarlık kazandırmakla, niteliksel ayrımsama yapmayı kazandırır. Kültürleri öğrenme yanında kültür üretiminin ve toplumsal gelişmenin önemli bir belirleyicisi olur (Kırışoğlu, 2005: 50).

Psikolojik, pedagojik, felsefi ve estetik alanlarda grift, çok yönlü olgular ve süreçleri içerir. Son zamanlarda öğrenci odaklı eğitimle bireylere kazandırılmak istenen araştırmacı, yapıcı, üretici kişilik sözü edilen sanat eğitim süreçleriyle verilir. Böyle bir eğitim, çevresine, olay ve olgulara duyarlı, biçim- mekân ilişkisini kavrayan, duyu ve duyumlarıla, imgesel düşünmesiyle akıl ve duygusunu dengeleyen bir yapıyı ortaya çıkartır. $\mathrm{Bu}$ şekilde kendisini rahatlıkla gerçekleştirebilen, güven duyan, bağımsız olabilen, kendisi ile birlikte çevresini de değiştirebilen, manipülasyonlara düşmeyen, kendisini dış dünyaya açık tutan, sadece bugüne değil geleceğe hazırlanan, sorumluluk duygusu gelişmiş, üretken ve dengeli bir kişilik kazandıran sanat eğitimi, sanatsal üretimi de kapsamaktadır (San, 1979: 178).

Yukarıda sözü edilen öğrenim çıktıları ya da amaçlar aslında toplumsal değerlere karşı duyarlı olmanın ötesinde, değer üreten bir yapıyı ortaya koymaktadır. Bu nedenle sanat eğitimi kendine özgü ilkeleri ile eğitimin her kademesinde yer almalı, nitelikli sanat eğitimcileri yetiştirilmeli ve halkın sanatsal beğeni düzeyini yükseltecek, onları nitelikli eserlerle buluşturacak ortamlar oluşturulmalıdır.

İnsanı bilgi, duygu ve davranış yönleriyle bir bütün olarak değerlendiren ve eğiten sanat eğitimi önemsenmelidir. Çünkü sanat insana özgü bir olgu, sanat eğitimi insanlığın eğitimidir. 


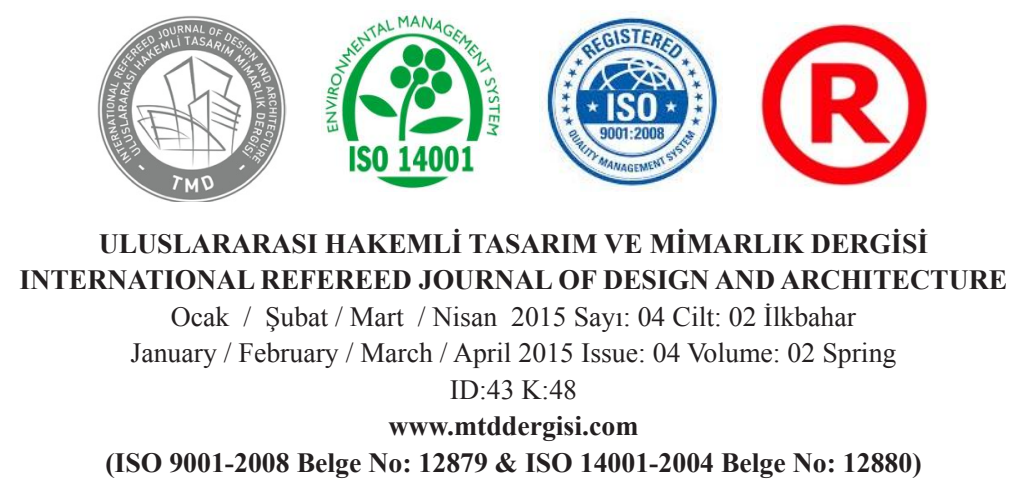

\section{KAYNAKLAR}

ADLER, $A$., (2013). İnsan Doğasını Anlamak,Çev. Deniz Başkaya, İlya Yayınevi, İzmir

ÇINAR, A.,(2006). “Modern Zamanların Değer Anlayış1: Varlık-Bilgi-Değer Birliğinin Önemi,” Değerler Eğitimi Dergisi, 4(11), ss. 53-68

KIRIŞOĞLU, O.,(2005). Sanatta Eğitim Yayıncılık, Pegem Akademi Yayınları, Ankara

KIRIŞOĞLU, O.,(2009). Sanat Kültür Yaratıc1lı, Görsel Sanatlar ve Kültür Eğitimi-Öğretimi, Pegem Akademi Yayınlan, Ankara

KIRIŞOĞLU, O.,(2014). Sanat Bir Serüven, Pegem Akademi Yayınlan, Ankara

KIRSCHENBAUM, H., (1995). 100 ways toenhancevaluesandmorality in schoolsandyouthsettings. Allyn\& Bacon Company, Massachusetts

LICKONA, T., (1992).Educationfor Character (How ourschools can teachrespectandresponsibility), BantomBooks, New York

ÖZENSEL, E., (2003).“Sosyolojik Bir Olgu Olarak Değer," Değerler Eğitimi Dergisi, 1 (3), ss. 217-239
ÖZLEM, D., (2002). “Doğa Bilimleri ve Sosyal Bilimler Ayrımının Dünü ve Bugünü Üzerine,” Toplum ve Bilim, say 176 , ss. 7-39

SAN, İ., (1979). “Yaratıcılık, İki Düşünce Biçimi ve Çocuğun Yaratıcı Eğitimi," AÜEF Dergisi, Cilt 12, say1 1-4, Ankara, ss. 170-190

SAN, I., (1983).Sanat Eğitimi Kuramları, Tan Yayınları, Ankara

THEODORSN, G. A., \& THEODORSN, A. (1979). A Modern Dictionary of Sociology, New York, Barnesand Noble

THOMSON, G., (1979). İnsanın Özü, Çev. Celal Üster, Payel Yayınevi, İstanbul

http://ahsar.blogcu.com/turk-milli-egitimininamaclari/2668493, 10.11.2014

http://mebk12.meb.gov.tr/meb iys dosyalar/03/07/748138/icerikler/anadolu-guzelsanatlar-liseleri 1, 10.11.2014

http://tyyc.yok.gov.tr/?pid=33,10.11.2014 